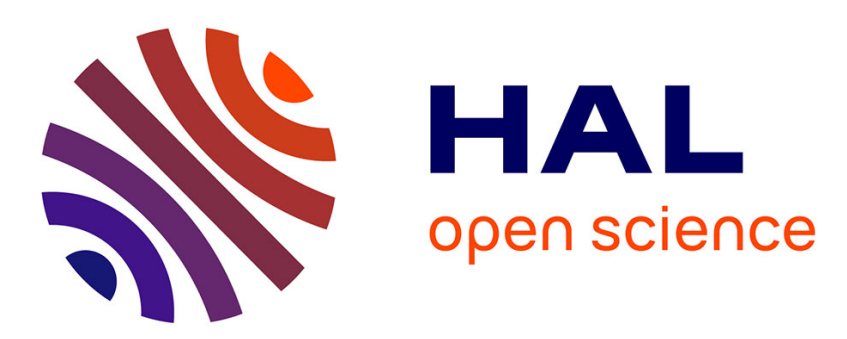

\title{
Hantavirus-specific IgA in saliva and viral antigen in the parotid gland in patients with hemorrhagic fever with renal syndrome
}

Lisa Pettersson, Johan Rasmuson, Charlotta Andersson, Clas Ahlm, Magnus Evander

\section{To cite this version:}

Lisa Pettersson, Johan Rasmuson, Charlotta Andersson, Clas Ahlm, Magnus Evander. Hantavirusspecific IgA in saliva and viral antigen in the parotid gland in patients with hemorrhagic fever with renal syndrome. Journal of Medical Virology, 2011, 83 (5), pp.864. 10.1002/jmv.22040 . hal-00616896

\section{HAL Id: hal-00616896 https://hal.science/hal-00616896}

Submitted on 25 Aug 2011

HAL is a multi-disciplinary open access archive for the deposit and dissemination of scientific research documents, whether they are published or not. The documents may come from teaching and research institutions in France or abroad, or from public or private research centers.
L'archive ouverte pluridisciplinaire HAL, est destinée au dépôt et à la diffusion de documents scientifiques de niveau recherche, publiés ou non, émanant des établissements d'enseignement et de recherche français ou étrangers, des laboratoires publics ou privés. 
Hantavirus-specific IgA in saliva and viral antigen in the parotid gland in patients with hemorrhagic fever with renal syndrome

\begin{tabular}{|r|l|}
\hline Journal: & Journal of Medical Virology \\
\hline Manuscript ID: & JMV-10-2157.R1 \\
\hline Diley - Manuscript type: & Research Article \\
\hline Complete List of Authors: & $\begin{array}{l}\text { Pettersson, Lisa; Umeå University, Clinical Microbiology/Division of } \\
\text { Virology } \\
\text { Rasmuson, Johan; Umeå University, Clinical Microbiology/Division } \\
\text { of Infectious diseases } \\
\text { Andersson, Charlotta; Umeå University, Medical } \\
\text { Biosciences/Division of Pathology } \\
\text { Ahlm, Clas; Umeå University, Clinical Microbiology/Division of } \\
\text { Infectious diseases } \\
\text { Evander, Magnus; Umeå University, Clinical Microbiology/Division of } \\
\text { Virology }\end{array}$ \\
\hline Keywords: & \begin{tabular}{l} 
Puumalavirus , HFRS, antibody, zoonosis, transmission \\
\hline
\end{tabular} \\
\hline
\end{tabular}

\section{SCHOLARONE ${ }^{\text {M }}$ \\ Manuscripts}


1 Hantavirus-specific IgA in saliva and viral antigen in the parotid gland in patients with

2 haemorrhagic fever with renal syndrome

$4 \quad$ Lisa Pettersson ${ }^{1}$, Johan Rasmuson ${ }^{2}$, Charlotta Andersson ${ }^{3}$, Clas Ahlm $^{2}$ and Magnus Evander ${ }^{1}$ *

5

$6{ }^{1}$ Department of Clinical Microbiology, Virology, ${ }^{2}$ Department of Clinical Microbiology,

7 Infectious Diseases, ${ }^{3}$ Department of Medical Biosciences, Pathology, Umeå University,

8 Umeå, Sweden.

9

*Corresponding author: Magnus Evander, Department of Clinical Microbiology, Virology,

11 Umeå University, S-901 85, Umeå, Sweden.

12 Phone: +46-90-7851790. Fax: +46-90-129905. E-mail: magnus.evander@climi.umu.se. 


\section{ABSTRACT}

2 The Hantavirus genus comprises rodent borne, zoonotic viruses of the Bunyaviridae family

3 that cause haemorrhagic fever with renal syndrome (HFRS) in Eurasia and hantavirus

4 cardiopulmonary syndrome (HCPS) in the Americas. Rodent saliva contains infectious

5 hantavirus and evidence suggests that hantavirus is also shed in human saliva, but person-

6 to-person transmission is rare. In saliva, immunoglobulin (Ig) A is the predominant

7 immunoglobulin class. Secretory IgA serves as an important first line of defence on epithelial

8 surfaces and the binding of secretory IgA to pathogens can inhibit adherence of

9 microorganisms to mucosal cells and neutralize viruses. This study investigated the presence and importance of salivary IgA in relation to viral antigen in the saliva by testing Puumala

11 hantavirus (PUUV) specific IgA, RNA, and antigen in saliva in acutely ill patients with HFRS. In 12 saliva samples, PUUV specific IgA was detected in twelve of 33 (36\%) patients with HFRS and 13 twenty (61\%) were PUUV RNA positive. There was a statistically significant inverse 14 association between the presence of salivary IgA antibodies and PUUV RNA in the saliva. 15 PUUV-specific IgA in saliva was not found in a long term follow-up, while PUUV IgA in serum was detected in three patients, 28-32 months after the initial study. Notably, both PUUV

17 RNA and PUUV nucleocapsid antigen were detected in endothelial cells within the parotid 18 gland of a deceased patient with HFRS.

Keywords: Puumalavirus, HFRS, HCPS, antibody, zoonosis, transmission 


\section{INTRODUCTION}

2 Viruses in the Hantavirus genus are rodent borne, zoonotic viruses of the Bunyaviridae

3 family and belong to the group of viral haemorrhagic fevers. Typically, hantaviruses cause

4 haemorrhagic fever with renal syndrome (HFRS) in Eurasia and hantavirus cardiopulmonary

5 syndrome (HCPS) in the Americas. HFRS symptoms include fever, renal failure, and

6 hemorraghia and HCPS symptoms include fever and severe pulmonary oedema; however,

7 between $10-30 \%$ of HFRS patients caused by Puumala virus (PUUV) (genus Hantavirus and

8 family Bunyaviridae) also display symptoms in the lower respiratory tract [Kanerva et al.,

9 1996; Linderholm et al., 1993; Linderholm et al., 1997]. The hantaviruses are negative stranded RNA- viruses consisting of spherical, enveloped particles 90 to $120 \mathrm{~nm}$ in diameter that contain two glycoproteins ( $\mathrm{Gn}$ and $\mathrm{Gc}$ ) and enclose three unique negative-stranded RNAs ( $L, M$, and $S$ ) associated with the RNA dependent RNA polymerase and the nucleocapsid protein. 2007; Martinez et al., 2005]. In a previous study, saliva from patients with HFRS was found to contain PUUV RNA [Pettersson et al., 2008]. Similarly, rodent saliva contains infectious hantavirus [Douron et al., 1984; Hardestam et al., 2008a; Padula et al., 2004; St Jeor, 2004]. 
1 person-to-person transmission, yet human saliva from HFRS patients containing PUUV RNA

2 has not been shown hitherto to be infectious [Hardestam et al., 2008b]. The reported

3 possibility of person-to-person transmission with the highly pathogenic ANDV (case-fatality

4 rate up to $40 \%$ ) raise concerns whether hantaviruses could constitute a risk for further

5 epidemic spread among humans. Consequently, presence of virus in saliva during infection

6 and factors that could enhance or decrease transmission are therefore of utmost interest.

7

8 Whole human saliva may inhibit the infectivity of several different viruses in vitro [Fox et al., 1988; Hartshorn et al., 2006]. In the Hantavirus genus, human saliva inhibited propagation in cell culture for PUUV and Hantaan virus (HTNV), while ANDV was less sensitive to the saliva antiviral effect [Hardestam et al., 2009]. Several components of human saliva could be responsible for this inhibition and mucin had some inhibitory effect on HTNV infection in vitro [Hardestam et al., 2008b]. Furthermore, presence of hantavirus-specific salivary antibodies in an infected individual could be important for protection against the disease and transmission. In saliva, Immunoglobulin (Ig) A is the predominant immunoglobulin class: it exists as polymeric $\lg A$ with a secretory component bound to the Ig molecules. This secretory IgA has increased resistance against proteolytic degradation. Secretory IgA is produced by plasma cells that are concentrated along mucous cell membrane surfaces and the daily production of IgA is greater than that of any other Ig class. The output in most secretions amounts to some $5-8 \mathrm{~g} /$ day in adults [Russel, 2007]. In serum, IgA constitutes only $10-15 \%$ of the total amount of Ig and exists primarily as a monomer. The parotid gland IgAto-IgG ratio is about 500 times increased compared to that in serum and $83-87 \%$ of salivary IgA in whole saliva is polymeric IgA [Brandtzaeg, 2007]. The secretory IgA serves as an 
1 important first line of defence on epithelial surfaces and the binding of secretory IgA to

2 pathogens can inhibit adherence of microorganisms to mucosal cells and neutralize viruses.

3 For instance, specific parotid and salivary IgA can neutralize Human immunodeficiency virus

4 type 1 (HIV-1) (family Retroviridae, subfamily Orthoretrovirinae, genus Lentivirus) [Devito et

5 al., 2002; Moja et al., 2000].

6 Only one study has described salivary IgA antibodies against hantavirus where ANDV-specific

7 IgA was detected in saliva (six patients with acute HCPS) [Padula et al., 2000]. In serum,

$8 \quad$ PUUV-specific IgA was shown to have a neutralizing effect against PUUV [de Carvalho

9 Nicacio et al., 2000]. The present study investigated the presence and importance of salivary IgA in relation to virus in saliva by analysing PUUV-specific IgA and viral RNA in saliva in acutely ill patients with HFRS. In addition, viral RNA and antigen were examined in a salivary gland of a fatal case with HFRS.

\section{MATERIALS AND METHODS}

\section{Patients and sample collection}

In part of a prospective study of patients with HFRS, saliva, plasma, and serum samples were collected from 33 consecutive patients verified by PUUV specific IgM or real-time RT-PCR at the Division of Infectious Diseases at Umeå University Hospital (Umeå, Sweden). The hospital is situated in the endemic area in northern Sweden. Patients were added to the study from January 2007 to February 2009. The patients were $26-82$ years (mean 52 years); 21 were female. The sample collection was performed during the acute phase as previously described [Pettersson et al., 2008] and was random with no consideration to time of day or recent food intake. For some patients, additional samples were obtained later in the acute phase. 
1 To study the long-term duration of PUUV-specific IgA, patients were invited for new

2 sampling in June 2010. Twelve patients agreed to participate in the follow-up and samples

3 were collected in the same manner as previously described. Tissue from the parotid salivary

4 gland was sampled at autopsy three days post-mortem from a patient with HFRS who died

5 five days post onset of disease.

$6 \quad$ All experiments were performed in compliance with relevant laws and institutional

7 guidelines and in accordance with the ethical standards of the Declaration of Helsinki. The

8 project was approved by the Regional Ethics Review Board in Umeå and informed consent

9 was obtained from all patients.

Real-time RT-PCR

RNA from patient saliva, plasma, or tissue was extracted using a QIAamp ${ }^{\circledR}$ Viral RNA kit (Qiagen, Inc., Valencia, CA, USA) according to the manufacturer's instructions. The real-time

RT-PCR was performed as previously described [Evander et al., 2007]. Briefly, the RNA was reverse-transcribed followed by a real-time PCR TaqMan ${ }^{\circledR}$ assay in triplets with PUUVspecific primers and probe from the S-segment. Taqman ${ }^{\circledR}$ RNAse P control reagents (Applied Biosystems, Foster City, CA, USA) were used to determine cell numbers in tissue. The real17 time PCR was performed using an ABI Prism 7900HT Sequence Detection System 2.0 18 (Applied Biosystems).

\section{Immunofluorescence assay (IFA)}

20 To detect PUUV-specific IgM and IgG antibodies in serum from patients with HFRS, IFA was 21 performed as described previously [Evander et al., 2007]. Briefly, the samples were diluted in 22 PBS (1:16 for IgM and 1:40 for IgG) and then applied onto spot-slide wells in a moist 
1 chamber with the local strain PUUV Umeå/hu [Johansson et al., 2004] grown in VeroE6 cells

2 as antigen at $37^{\circ} \mathrm{C}$ over night for $\operatorname{lgM}$ analysis and 60 minutes at $20^{\circ} \mathrm{C}$ for $\operatorname{lgG}$ analysis. For $\operatorname{lgA}$

3 analysis, the same antigen was used to detect PUUV-specific IgA antibodies in serum and

4 saliva. The slides were incubated over night with patient saliva (diluted 1:10) and 90 minutes

5 with serum (diluted $1: 10$ and $1: 40$ ) at $37^{\circ} \mathrm{C}$ and then PUUV-specific IgA antibodies were

6 detected by a polyclonal rabbit anti-human IgA-FITC (F0204, DAKO A/S, Glostrup, Denmark)

7 diluted $1: 40$ and incubated 60 minutes at $37^{\circ} \mathrm{C}$. The salivary IgA results were confirmed by

8 detection of PUUV-specific salivary IgA antibodies using another detecting antibody - the

9 anti-human IgA-FITC (diluted 1:30) (AF010.M, Binding Site Itd, Birmingham, UK).

\section{Immunohistochemistry}

11 The parotid salivary gland was examined for presence of viral antigen using PUUV nucleocapsid protein specific monoclonal antibody (A1C5, Progen Biotechnik GmbH, Heidelberg, Germany). Staining was performed on formalin-fixed paraffin-embedded $4 \mu \mathrm{m}$ sections that were processed for immunohistochemistry using a biotin, streptavidin, and peroxidase technique visualized with diaminobenzidine. Parotid samples from two nonhantavirus patients were used as negative controls.

\section{Statistical analysis}

18 For statistical calculations and graphs, the SPSS software (SPSS, Inc., Chicago, USA) was used.

19 Associations between parameters were evaluated using the Mann-Whitney U test. P values $<0.05$ were considered statistically significant. 


\section{$1 \quad$ RESULTS}

\section{PUUV-specific RNA in saliva and plasma from acute phase}

3 Of the 33 patients, 20 (61\%) had PUUV RNA in their saliva and $27(82 \%)$ in their plasma

4 (Table 1). The mean value of viral copy number in PUUV RNA positive samples was 33,091

5 copies/ml in saliva and 113,460 copies/ $\mathrm{ml}$ in plasma, with a wide range between samples

6 (Table 1). Interestingly, PUUV RNA was detected in saliva (as long as 15 days) and plasma (as

7 long as 20 days) after disease onset (Table 1). As expected, in patients where saliva and

8 plasma were collected consecutively, the RNA-levels decreased with time (Table 1).

9 In patients where plasma and saliva were collected on the same day (for patients with additional samples only one sample pair was evaluated), twelve of 19 sample pairs were

11 PUUV RNA positive in both saliva and plasma, three were negative in both, four were only positive in plasma, and no sample was only positive in saliva (Table 1 and Table 2). There was a significant association between presence of PUUV RNA in saliva and plasma samples, and the RNA levels in plasma were significantly higher in RNA positive than in RNA negative saliva ( $P=0.010$, Mann-Whitney $U$ test $)$.

PUUV-specific antibodies in serum from acute phase

PUUV-specific IgA, IgM or IgG were found in the sera from all patients at first visit. The only patient with a negative IgA serum (no. 27, Table 1) was IgG and IgM positive in the serum and IgA negative in the saliva. Interestingly, this patient had been sick for six days and had an extremely high viral load in the serum, $1.38 \times 10^{6}$ copies $/ \mathrm{ml}$. Three patients were only weakly positive for PUUV-specific IgA in serum (no. 20, 28 and 30, Table 1). Notably, the only patients with negative IgM and IgG in the serum were found in this group (no. 28 and 20 
1 respectively) and all three were IgA negative in the saliva. The sample with negative IgG (no.

2 20, Table 1) was collected only three days after disease onset and had high viral copy

3 number in the plasma. After two additional days, the patient was positive for IgG in serum.

4 The patient with serum negative for PUUV IgM (no. 28) was positive for PUUV RNA both in 5 plasma and saliva (Table 1).

\section{$6 \quad$ PUUV-specific antibodies in saliva from acute phase}

$7 \quad$ PUUV-specific IgA in the saliva was detected in eleven patients at the initial visit (Table 1)

8 and in one additional patient two days later (no. 12, Table 1). In total, twelve of 33 patients

9 with HFRS had salivary IgA and there was a statistically significant inverse association ( $P=0.009$, Mann-Whitney $\mathrm{U}$ test) between presence of salivary IgA antibodies and PUUV RNA in the saliva samples (Fig. 1). Of the eleven patients with HFRS with salivary IgA antibodies in disappearance of PUUV RNA in the patient's saliva (Table 1).

Long-term follow-up of PUUV-specific IgA antibodies in saliva and serum

To study the long-term duration of PUUV-specific $\lg A$, patients were invited for a follow-up sampling between 17 months and 32 months after falling ill with HFRS. Twelve patients 
1 agreed to give a follow-up saliva and serum sample. All subjects were negative for IgM and

2 positive for IgG at this time. One patient (no. 13, Table 1) was positive for PUUV IgA in the

3 serum 32 months after the first sample, and two patients (no. 5 and 22, Table 1) were

4 weakly positive for IgA in their serum samples after 29 months and 28 months, respectively.

5 These three patients were all negative for IgM and positive for IgG at follow-up. The

6 remaining patients were negative for $\lg A$ in their sera. All patients were negative for $\lg A$ in

7 the saliva. No PCR was performed in the follow-up samples.

8 PUUV IgA and RNA in serum and saliva in relation to airway symptoms, treatment, and

9 radiological findings

10 In addition to the typical symptoms and clinical signs of HFRS, 22 (67\%) patients had

11 respiratory tract symptoms. Perhaps, PUUV RNA and PUUV-specific IgA originated from the

12 lungs through coughing and may be more abundant in individuals where lungs and airways

13 are affected. Seventeen of the 22 HFRS patients with respiratory tract symptoms had

14 dyspnea and 13 were coughing. Eight of the patients were treated with oxygen due to low

15 oxygen-saturation in the blood. A chest x-ray was performed on 12 patients; nine of these

16 were pathological (including infiltrates and/or pleural fluid) and three were normal.

17 However, no statistical significant associations (Mann-Whitney $U$ test) were found between

18 presence of PUUV-specific IgA or PUUV RNA in their saliva or plasma and symptoms,

19 treatment, and radiological findings (data not shown).

20 Presence of PUUV antigen and RNA in a human salivary gland

21 To further investigate whether PUUV RNA present in the saliva could originate from the

22 salivary glands, a parotid salivary gland sample from a patient with HFRS was analysed for 
1 presence of PUUV RNA and PUUV antigen using a monoclonal antibody (A1C5) specific for

2 the PUUV nucleocapsid protein. Using immunohistochemistry, the PUUV nucleocapsid

3 antigen was detected in the capillary endothelium and within mononuclear cells (Fig. 2).

4 Using real-time RT-PCR, 19 PUUV RNA copies/10,000 cells were demonstrated in the salivary

5 gland sample and 18,000 PUUV RNA copies/ml in the tracheal secretions. Unfortunately, no

6 saliva had been collected from this patient. Parotid samples from two non-hantavirus

7 patients were both negative for nucleocapsid antigen (data not shown).

8

9

\section{DISCUSSION}

Can hantavirus in human saliva be infectious, and if not, why? In the studied patients with HFRS, both PUUV RNA and nucleocapsid antigen were found in the saliva and salivary gland, respectively. Presence of hantavirus in saliva could potentially promote transmission unless salivary components inhibit this infectivity route.

Both PUUV RNA and nucleocapsid antigen were detected in a human parotid gland. The viral antigen was demonstrated in the capillary endothelium and within mononuclear cells; however, no staining was found within the secretory epithelium. The findings indicate that virus found in saliva can be the result of shedding from the salivary gland. Presence of hantavirus antigen in the human salivary glands has not previously been published, but hantavirus antigen in rodent and mouse salivary glands has been demonstrated [Botten et al., 2000; Compton et al., 2004; Lee et al., 1981]. Hantavirus is infectious in rodent saliva and experimental studies with sigmodontine rodents hosting ANDV have investigated the hypothesis that saliva is one of the sources of infection within reservoir populations [Padula 
1 et al., 2004]. Person-person transmission of ANDV has been suggested to be mediated by

2 close contact, such as having a sexual relations or engaging in intimate kissing with a person

3 infected with hantavirus [Ferres et al., 2007; Martinez et al., 2005]. One of the studies

4 suggests that the unique route of transmission of ANDV is by means of small-particle

5 infectious saliva or respiratory aerosols during the close contact between both persons

6 [Martinez et al., 2005] .For other hantaviruses, this type of transmission has not been

7 demonstrated and, except for ANDV, whole human saliva has an inhibitory effect on several

8 hantaviruses in vitro [Hardestam et al., 2009]. Hantavirus-specific antibodies could also play

9 a role in decreasing the possibility for transmission during an infection.

In the study, the presence of secretory IgA antibodies in the saliva of a patient with HFRS was significantly inversely associated with the presence of PUUV RNA in saliva, suggesting that the virus could be contagious before appearance of salivary IgA. Increased titers of IgG antibodies in the serum of patients with HFRS coincide with the disappearance of PUUV RNA in the plasma [Evander et al., 2007] and similar kinetics of the virus-antibody relationship may occur in the human oral cavity. For other viruses, it has been shown that secretory IgA protects against infection [Belec et al., 2003; Renegar et al., 2004]. Hantavirus-specific IgA in saliva could potentially provide protection against person-to-person transmission. For HIV-1, specific salivary IgA neutralises infection in vitro and mucosal IgA seems to be more efficient than serum IgA [Moja et al., 2000], which could be explained by the polymeric structure of the mucosal secretory IgA [Hocini et al., 1997]. In addition, the antibody function of secretory IgA is most likely enhanced by the high level of cross-reacting activity detected in human secretions [Ma et al., 1998]. Only one study has described detection of salivary IgA antibodies in hantavirus disease; the study used ANDV nucleoprotein expressed in 
1 Escherichia coli as antigen in an ELISA [Padula et al., 2000]. In that report, ANDV-specific

2 salivary IgA was detected in six patients with HCPS up to a month after onset of symptoms

3 [Padula et al., 2000]. Similarly, the present study found one patient with HFRS who displayed

$4 \quad$ IgA antibodies in the saliva 32 days after disease onset. Furthermore, PUUV RNA was

5 detected in the saliva and plasma from patients with HFRS more than two weeks after

6 disease onset, a finding that is also similar to previous reports on PUUV RNA in plasma

7 [Evander et al., 2007; Saksida et al., 2008]. A decreased nucleocapsid-specific serum IgA

8 response in convalescent and late-convalescent-phase sera has been observed in serum

9 from patients with HFRS [de Carvalho Nicacio et al., 2000; Elgh et al., 1998; Groen et al., 10 1994; Meisel et al., 2006; Padula et al., 2004], a finding also similar to the present study; 11 however, serum IgA could be detected in convalescent sera for up to ten years [de Carvalho 12 Nicacio et al., 2000]. The possibility of boosting with hantavirus during the follow-up period cannot be excluded. In the present study, samples from 12 patients with HFRS more than two years after disease were all negative for PUUV-specific IgA in their saliva, while three patients were still IgA positive in sera.

In the acute phase, all patients but one had serum IgA while the proportion of detectable IgA in saliva was lower. PUUV-specific IgA directed both against hantavirus nucleocapsid and glycoproteins was detected since the antigen in the IFA consisted of PUUV-infected cells. The conjugate used to reveal IgA allowed recognition of all potential molecular forms of PUUVspecific IgA antibodies - e.g., monomeric, dimeric, and secretory IgA - but close to $90 \%$ of salivary IgA in whole saliva is polymeric IgA [Brandtzaeg, 2007]. In most samples, IgA was not detectable in saliva until the PUUV-RNA was cleared, which is in contrast to serum, where 
1 IgA was detected regardless whether PUUV-RNA was present or not. Complexes in the

2 saliva, including PUUV-specific IgA and PUUV particles, might cause a negative IFA result. In

3 the oral cavity, secretory IgA is known to exist in complex with salivary agglutinin (agglutinin

4 gp-340; [Ligtenberg et al., 2004] and mucin [Biesbrock et al., 1991; Wickstrom et al., 2000]

5 and they inhibit infection by aggregation with virus [Habte et al., 2006; Hartshorn et al.,

6 2006]. Further studies that optimize hantavirus IgA detection in salivary samples could

7 increase the sensitivity of IgA detection. In the present study, PUUV RNA was detected both

8 in saliva and plasma and virus RNA in saliva was associated with viremia in patients with

9 HFRS, indicating that analysis of oral fluid could be useful for molecular investigation during

10 outbreaks. Saliva is an attractive non-invasive sample for diagnostics and epidemiological

11 studies and oral fluid samples have been shown to be useful for many infectious agents such

12 as the early detection of HIV [Nugent et al., 2009]. Determination of specific viral nucleic

13 acids and antibodies in saliva samples makes this test even more useful for isolated

14 communities and it has been suggested as a sampling technique for some native populations

15 in South America who, due to cultural reasons, do not always accept venepuncture [Padula

16 et al., 2000]. The direct detection and identification of many viruses in saliva by PCR could

17 become a standard method and numerous studies on different viruses have been reported

18 [Corstjens and Malamud, 2008]. Detection of hantavirus-specific secretory IgA is non-

19 invasive technique and has a promising future as a diagnostic tool. In addition, hantavirus-

20 specific secretory IgA could provide insight into the dynamics of hantavirus infection in

21 relation to the host immune response. Here, PUUV-specific salivary IgA was present in saliva

22 of infected patients and appearance of salivary IgA was associated with the disappearance of 23 the virus. 
1

\section{ACKNOWLEDGEMENTS}

3 Irene Eriksson is greatly acknowledged for her skilled technical assistance. This project was

4 supported by grants from the Kempe Foundation, The Swedish Heart-Lung Foundation, the

5 Swedish Society of Medical Microbiology, the County Councils of Northern Sweden, the

6 County Council of Västerbotten, and the Medical faculty of Umeå University. 
1

2

3

4

5

6

7

8

9

\section{REFERENCES}

Belec L, Legoff J, Si-Mohamed A, Bloch F, Mbopi Keou FX, Becquart P, Matta M, Prazuck T, Petite JP, Gutmann L, Payan C. 2003. Mucosal humoral immune response to hepatitis C virus E1/E2 surface glycoproteins and HCV shedding in saliva and cervicovaginal fluids from chronically HCV-infected patients. J Hepatol 38:833-842.

Biesbrock AR, Reddy MS, Levine MJ. 1991. Interaction of a salivary mucin-secretory immunoglobulin A complex with mucosal pathogens. Infect Immun 59:3492-3497.

Botten J, Mirowsky K, Kusewitt D, Bharadwaj M, Yee J, Ricci R, Feddersen RM, Hjelle B. 2000. Experimental infection model for Sin Nombre hantavirus in the deer mouse (Peromyscus maniculatus). Proc Natl Acad Sci U S A 97:10578-10583.

Brandtzaeg P. 2007. Do salivary antibodies reliably reflect both mucosal and systemic immunity? Ann N Y Acad Sci 1098:288-311.

Compton SR, Jacoby RO, Paturzo FX, Smith AL. 2004. Persistent Seoul virus infection in Lewis rats. Arch Virol 149:1325-1339.

Corstjens P, Malamud D. 2008. Point-of-care diagnostics for infectious diseases. In: Wong D, editor. Salivary Diagnostics. Ames, lowa, USA: Wiley-Blackwell. p 140-143.

de Carvalho Nicacio C, Lundkvist A, Sjolander KB, Plyusnin A, Salonen EM, Bjorling E. 2000. A neutralizing recombinant human antibody Fab fragment against Puumala hantavirus. J Med Virol 60:446-454.

Devito C, Hinkula J, Kaul R, Kimani J, Kiama P, Lopalco L, Barass C, Piconi S, Trabattoni D, Bwayo JJ, Plummer F, Clerici M, Broliden K. 2002. Cross-clade HIV-1-specific neutralizing IgA in mucosal and systemic compartments of HIV-1-exposed, persistently seronegative subjects. J Acquir Immune Defic Syndr 30:413-420. 
1 Douron E, Moriniere B, Matheron S, Girard PM, Gonzalez JP, Hirsch F, McCormick JB. 1984. HFRS

2

3

4

5

6

7 after a wild rodent bite in the Haute-Savoie--and risk of exposure to Hantaan-like virus in a Paris laboratory. Lancet 1:676-677.

Elgh F, Linderholm M, Wadell G, Tarnvik A, Juto P. 1998. Development of humoral cross-reactivity to the nucleocapsid protein of heterologous hantaviruses in nephropathia epidemica. FEMS Immunol Med Microbiol 22:309-315.

Evander M, Eriksson I, Pettersson L, Juto P, AhIm C, Olsson GE, Bucht G, Allard A. 2007. Puumala hantavirus viremia diagnosed by real-time reverse transcriptase PCR using samples from patients with hemorrhagic fever and renal syndrome. J Clin Microbiol 45:2491-2497.

Ferres M, Vial P, Marco C, Yanez L, Godoy P, Castillo C, Hjelle B, Delgado I, Lee SJ, Mertz GJ. 2007. Prospective evaluation of household contacts of persons with hantavirus cardiopulmonary syndrome in chile. J Infect Dis 195:1563-1571.

Fox PC, Wolff A, Yeh CK, Atkinson JC, Baum BJ. 1988. Saliva inhibits HIV-1 infectivity. J Am Dent Assoc 116:635-637.

Groen J, Gerding M, Jordans JG, Clement JP, Osterhaus AD. 1994. Class and subclass distribution of Hantavirus-specific serum antibodies at different times after the onset of nephropathia epidemica. J Med Virol 43:39-43.

Habte HH, Mall AS, de Beer C, Lotz ZE, Kahn D. 2006. The role of crude human saliva and purified salivary MUC5B and MUC7 mucins in the inhibition of Human Immunodeficiency Virus type 1 in an inhibition assay. Virol J 3:99.

Hardestam J, Karlsson M, Falk KI, Olsson G, Klingstrom J, Lundkvist A. 2008a. Puumala hantavirus excretion kinetics in bank voles (Myodes glareolus). Emerg Infect Dis 14:1209-1215.

Hardestam J, Lundkvist A, Klingstrom J. 2009. Sensitivity of Andes hantavirus to antiviral effect of human saliva. Emerg Infect Dis 15:1140-1142. 
1 Hardestam J, Petterson L, AhIm C, Evander M, Lundkvist A, Klingstrom J. 2008b. Antiviral effect of

2

3

4

5

6

7

8 human saliva against hantavirus. J Med Virol 80:2122-2126.

Hartshorn KL, Ligtenberg A, White MR, Van Eijk M, Hartshorn M, Pemberton L, Holmskov U, Crouch E. 2006. Salivary agglutinin and lung scavenger receptor cysteine-rich glycoprotein 340 have broad anti-influenza activities and interactions with surfactant protein $D$ that vary according to donor source and sialylation. Biochem J 393:545-553.

Hocini H, Belec L, Iscaki S, Garin B, Pillot J, Becquart P, Bomsel M. 1997. High-level ability of secretory IgA to block HIV type 1 transcytosis: contrasting secretory IgA and IgG responses to glycoprotein 160. AIDS Res Hum Retroviruses 13:1179-1185.

Johansson P, Olsson M, Lindgren L, Ahlm C, Elgh F, Holmstrom A, Bucht G. 2004. Complete gene sequence of a human Puumala hantavirus isolate, Puumala Umea/hu: sequence comparison and characterisation of encoded gene products. Virus Res 105:147-155.

Kanerva M, Paakkala A, Mustonen J, Paakkala T, Lahtela J, Pasternack A. 1996. Pulmonary involvement in nephropathia epidemica: radiological findings and their clinical correlations. Clin Nephrol 46:369-378.

Lee HW, Lee PW, Baek LJ, Song CK, Seong IW. 1981. Intraspecific transmission of Hantaan virus, etiologic agent of Korean hemorrhagic fever, in the rodent Apodemus agrarius. Am J Trop Med Hyg 30:1106-1112.

Ligtenberg AJ, Bikker FJ, De Blieck-Hogervorst JM, Veerman EC, Nieuw Amerongen AV. 2004. Binding of salivary agglutinin to IgA. Biochem J 383:159-164.

Linderholm M, Bjermer L, Juto P, Roos G, Sandstrom T, Settergren B, Tarnvik A. 1993. Local host response in the lower respiratory tract in nephropathia epidemica. Scand J Infect Dis 25:639646. 
1 Linderholm M, Sandstrom T, Rinnstrom O, Groth S, Blomberg A, Tarnvik A. 1997. Impaired pulmonary

2

3 function in patients with hemorrhagic fever with renal syndrome. Clin Infect Dis 25:10841089.

Ma JK, Hikmat BY, Wycoff K, Vine ND, Chargelegue D, Yu L, Hein MB, Lehner T. 1998. Characterization of a recombinant plant monoclonal secretory antibody and preventive immunotherapy in humans. Nat Med 4:601-606.

Martinez VP, Bellomo C, San Juan J, Pinna D, Forlenza R, Elder M, Padula PJ. 2005. Person-to-person transmission of Andes virus. Emerg Infect Dis 11:1848-1853.

Meisel H, Wolbert A, Razanskiene A, Marg A, Kazaks A, Sasnauskas K, Pauli G, Ulrich R, Kruger DH. 2006. Development of novel immunoglobulin G (IgG), IgA, and IgM enzyme immunoassays based on recombinant Puumala and Dobrava hantavirus nucleocapsid proteins. Clin Vaccine Immunol 13:1349-1357.

Moja P, Tranchat C, Tchou I, Pozzetto B, Lucht F, Desgranges C, Genin C. 2000. Neutralization of human immunodeficiency virus type 1 (HIV-1) mediated by parotid IgA of HIV-1-infected patients. J Infect Dis 181:1607-1613.

Nugent CT, Dockter J, Bernardin F, Hecht R, Smith D, Delwart E, Pilcher C, Richman D, Busch M, Giachetti C. 2009. Detection of HIV-1 in alternative specimen types using the APTIMA HIV-1 RNA Qualitative Assay. J Virol Methods 159:10-14.

Padula P, Figueroa R, Navarrete M, Pizarro E, Cadiz R, Bellomo C, Jofre C, Zaror L, Rodriguez E, Murua R. 2004. Transmission study of Andes hantavirus infection in wild sigmodontine rodents. J Virol 78:11972-11979.

Padula PJ, Rossi CM, Della Valle MO, Martinez PV, Colavecchia SB, Edelstein A, Miguel SD, Rabinovich RD, Segura EL. 2000. Development and evaluation of a solid-phase enzyme immunoassay based on Andes hantavirus recombinant nucleoprotein. J Med Microbiol 49:149-155. 
1 Pettersson L, Klingstrom J, Hardestam J, Lundkvist A, Ahlm C, Evander M. 2008. Hantavirus RNA in

2

3

4

5

6

7

8

9

10

11

12 saliva from patients with hemorrhagic fever with renal syndrome. Emerg Infect Dis 14:406411.

Renegar KB, Small PA, Jr., Boykins LG, Wright PF. 2004. Role of IgA versus IgG in the control of influenza viral infection in the murine respiratory tract. J Immunol 173:1978-1986.

Russel M. 2007. Mucosal immune defense:Immunoglobulin A. Kaetzel C, editor. N.Y.: Springer Science. 144-172 p.

Saksida A, Duh D, Korva M, Avsic-Zupanc T. 2008. Dobrava virus RNA load in patients who have hemorrhagic fever with renal syndrome. J Infect Dis 197:681-685.

St Jeor SC. 2004. Three-week incubation period for hantavirus infection. Pediatr Infect Dis J 23:974975.

Wickstrom C, Christersson C, Davies JR, Carlstedt I. 2000. Macromolecular organization of saliva: identification of 'insoluble' MUC5B assemblies and non-mucin proteins in the gel phase. Biochem J 351 Pt 2:421-428. 
1

2

3

4

5

6

7

8

\section{FIGURE LEGENDS}

2

3 Figure 1. Inverse association between presence of IgA antibodies and PUUV RNA in saliva

4 samples $(P=0.009)$. Mean saliva PUUV RNA copy number was 30,960 copies $/ \mathrm{ml}$ in patients

5 without PUUV-specific salivary IgA and 2,046 copies/ml in patients with PUUV-specific

6 salivary $\lg A$.

$7{ }^{\circ}$ Outlier, * Extreme outlier

8

9 Figure 2. PUUV nucleocapsid antigen in the parotid salivary gland of an HFRS patient. Using

10 PUUV nucleocapsid protein specific monoclonal antibody and immunohistochemistry

11 technique, viral antigen was demonstrated within the capillary endothelium of the organ.

12 Specific punctuate granular staining within the capillary endothelial walls are indicated. 
Table 1. PUUV-specific IgA and RNA in HFRS patients.

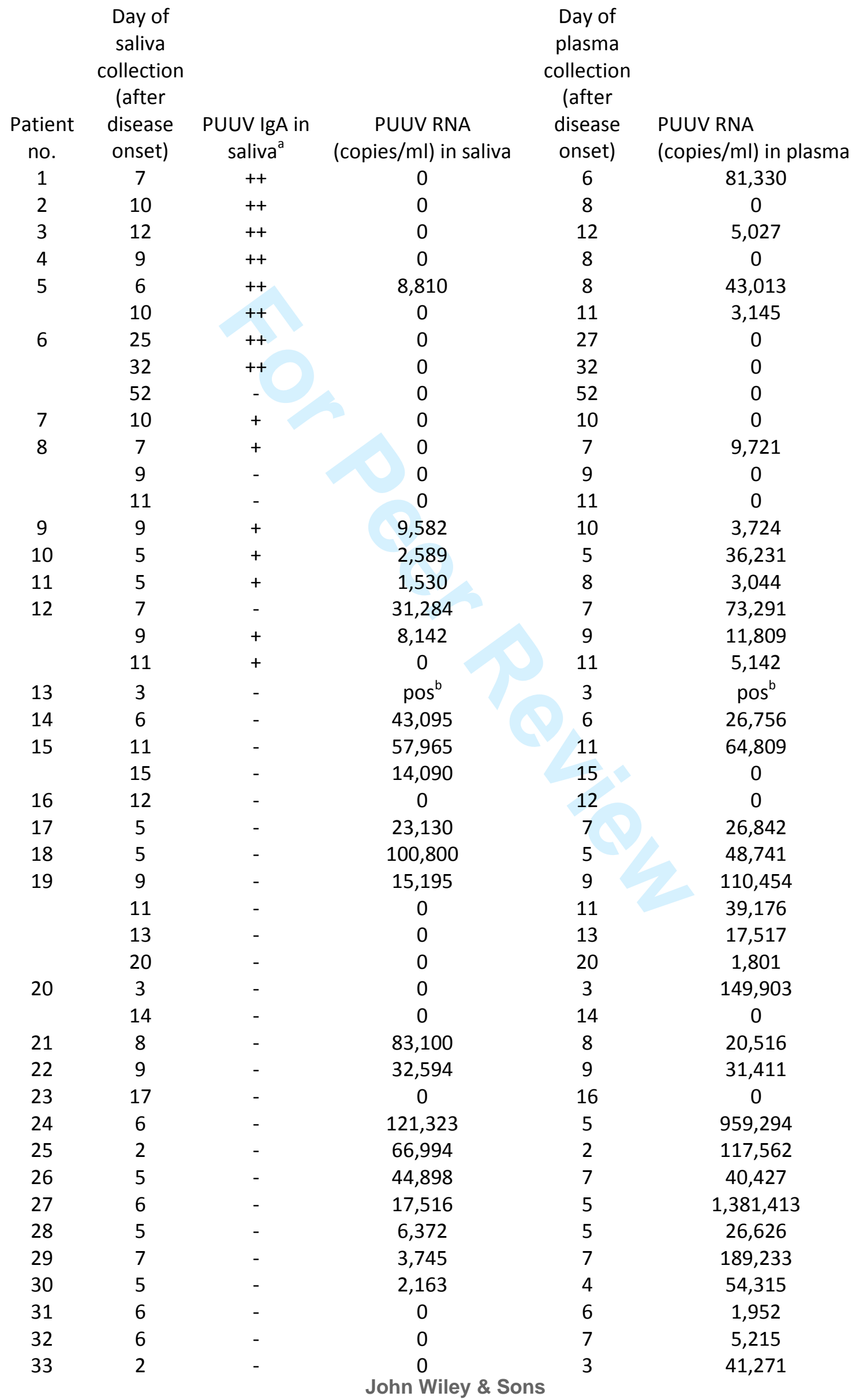


${ }^{\mathrm{a}}$ IgA was diluted 1:10 and scored as negative (-), strongly positive (++) or weakly positive (+) by IF.

${ }^{b}$ PUUV-specific PCR on patient 13 was only performed by conventional PCR and scored as positive (pos) or negative. 
Inverse association between presence of IgA antibodies and PUUV RNA in saliva samples ( $P=$ 0.009 ). Mean saliva PUUV RNA copy number was 30,960 copies $/ \mathrm{ml}$ in patients without PUUVspecific salivary IgA and 2,046 copies/ml in patients with PUUV-specific salivary IgA.

- Outlier, * Extreme outlier

$166 \times 130 \mathrm{~mm}(96 \times 96 \mathrm{DPI})$ 


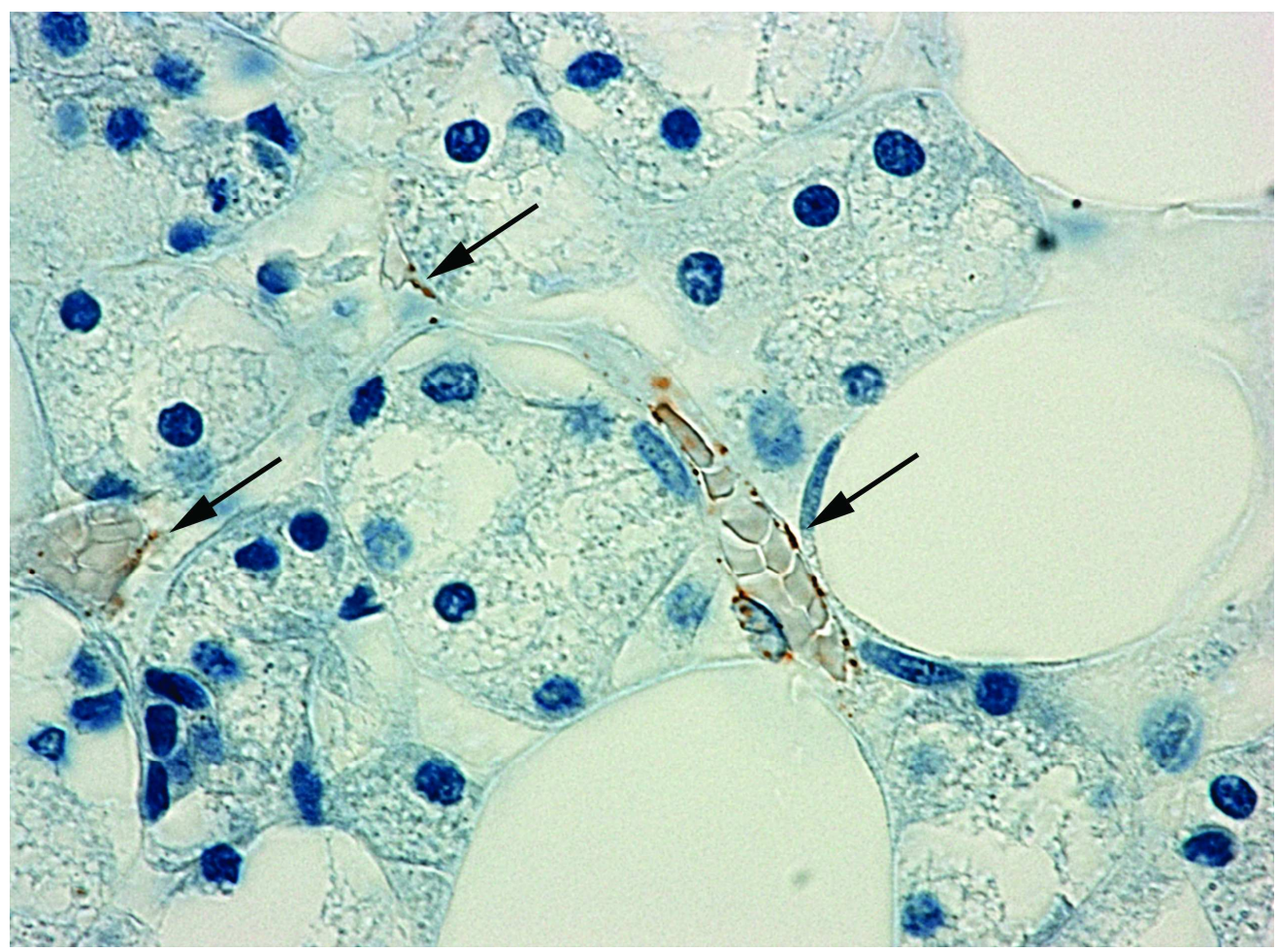

PUUV nucleocapsid antigen in the parotid salivary gland of an HFRS patient. Using PUUV nucleocapsid protein specific monoclonal antibody and immunohistochemistry technique, viral antigen was demonstrated within the capillary endothelium of the organ. Specific punctuate granular staining within the capillary endothelial walls are indicated.

$215 \times 159 \mathrm{~mm}(300 \times 300$ DPI $)$ 